\title{
T-Type Calcium Channels: Heterogeneous Expression in Rat Sensory Neurons and Selective Modulation by Phorbol Esters
}

\author{
J. E. Schroeder, P. S. Fischbach, and E. W. McCleskey \\ Department of Cell Biology and Physiology, Washington University, St. Louis, Missouri 63110
}

\begin{abstract}
We report selective inhibition of low-threshold, T-type calcium channels by a phorbol ester in rat sensory neurons. Cells were exposed, either acutely or with 15-60 min preincubations, to low concentrations of phorbol 12-myristate 13-acetate, (PMA), an activator of protein kinase $C$; if the temperature was $29^{\circ} \mathrm{C}$ or higher, T-type Ca current was diminished without effect on high-threshold Ca current. In untreated cells, the amplitude of T-type Ca current varies widely among neighboring sensory neurons. $T$ channels are absent in about $\mathbf{2 5} \%$ of cells, provide a small current near threshold for the majority of cells, and are a dominant pathway for calcium entry in a small subset of neurons. The results are of interest because, by selectively inhibiting a calcium channel expressed differently among subpopulations of sensory neurons, activation of protein kinase $\mathrm{C}$ might selectively suppress particular sensations.
\end{abstract}

T channels are a class of voltage-activated calcium (Ca) channel present on cardiac muscle, smooth muscle, secretory cells, fibroblasts, and neurons (for reviews, see Tsien et al., 1988; Bean, 1989), including the mammalian sensory neurons discussed in this paper (Bossu et al., 1985; Fedulova et al., 1985; Bossu and Feltz, 1986; Carbone and Lux, 1987; Kostyuk and Shirokov, 1989). They enhance the excitability and promote bursting of central neurons (Jahnsen and Llinás, 1984; McCormick and Prince, 1988; White et al., 1989) and help determine firing frequency of cardiac pacemaking cells (Hagiwara et al., 1988). Kinetic criteria distinguish $\mathrm{T}$ channels from the higher-threshold N- and L-type Ca channels (Carbone and Lux, 1984, 1987; Armstrong and Matteson, 1985; Nowycky et al., 1985; Matteson and Armstrong, 1986; Fox et al., 1987a, b). Activating at membrane voltages positive to $-50 \mathrm{mV}$, T channels can be recorded in isolation from the other Ca channels, which activate above $-30 \mathrm{mV}$. $\mathrm{T}$ channels inactivate during a maintained stimulus more rapidly than other Ca channels but turn off more slowly upon cessation of a bricf stimulus. The $2 \mathrm{kcy}$ functional properties of $\mathrm{T}$ channels are (1) activation, which occurs at membrane voltages near the threshold for action potentials, and (2)

\footnotetext{
Received Aug. 3, 1989; revised Sept. 25, 1989; accepted Sept. 27, 1989.

We thank Drs. Gerald Fischbach, Joel Brown, and Jeanne Nerbonne for helpful comments on the manuscript, Dr. Jane Dodd for advice on culture and dissection methods, and Mulu Mamo for help in preparing figures. Supported by NIH grant R29-GM38178-02, a grant from the Monsanto Chemical Company, and a Presidential Young Investigator Award from the NSF to E.W.M.

Correspondence should be addressed to Ed McCleskey, Department of Cell Biology and Physiology, \#8228, Washington University of School of Medicine, 660 S. Euclid Ave., St. Louis, MO 63110.

Copyright (c) 1990 Society for Neuroscience $0270-6474 / 90 / 030947-05 \$ 02.00 / 0$
}

inactivation, which occurs when cells are persistently held at voltages above $-50 \mathrm{mV}$. Thus, variation of neuronal rest potential affects the availability of $T$ channels, which in turn affects the excitability of the cell.

In embryonic chick sensory neurons, activation of protein kinase $\mathrm{C}$ with phorbol esters and diacylglycerol analogs inhibits nonselectively both high-threshold and T-type Ca channels (Rane and Dunlap, 1986; Marchetti and Brown, 1988; Rane et al., 1989). In this paper, we show a selective effect of phorbol esters on $\mathrm{T}$ channels in sensory neurons of newborn rat dorsal root ganglia and demonstrate heterogeneous expression of $\mathrm{T}$ channels among apparent subpopulations of these cells.

\section{Materials and Methods}

Tissue culture. Culture methods were modified from Yamamoto et al. (1981). Dorsal root ganglia from 5-10 d postnatal rats were dissociated in $\mathrm{Ca} / \mathrm{Mg}$-free Hanks solution (Sigma Chemical Co., St. Louis, MO) containing $25 \mu \mathrm{M} \mathrm{CaCl}_{2}, 0.2 \%$ trypsin (GIBCO, Life Technologies, Inc. Grand Island, NY) and 0.01 or $0.1 \%$ (for $10 \mathrm{~d}$ rats) collagenase (Cls II Cooper Biomedical, Malvern, PA). Cells were grown on coverslips coated with collagen (Biomedical Technologies, Stoughton, MA) at $37^{\circ} \mathrm{C}$ and $5 \% \mathrm{CO}_{2}$ and studied after $1-14 \mathrm{~d}$ in culture. Culture medium was as follows: Ham's F12 (GIBCO) with 10\% fetal calf serum (HyClone Laboratories, Logan, UT), $100 \mathrm{units} / \mathrm{ml}$ penicillin, $100 \mu \mathrm{g} / \mathrm{ml}$ streptomycin, $5 \mathrm{mg} / \mathrm{ml}$ glucose, and $100 \mathrm{ng} / \mathrm{ml}$ nerve growth factor (from Vipera Libetina, Sigma).

Some cells studied after $1 \mathrm{~d}$ in culture did not have processes, but most did. Process formation was dramatically greater on laminin-coated coverslips compared with collagen; the extensive processes caused intolerable space-clamp problems after a day in culture on laminin coverslips. Diameters varied from $10-30 \mu \mathrm{m}$ for those cells used for recordings.

Recordings and experimental solutions. All recordings used the wholecell patch clamp (Hamill et al., 1981). Leak and capacity currents were eliminated by digitally scaling and subtracting records obtained with subthreshold voltage pulses.

Experimental temperature was monitored with a bath thermistor and controlled by constant flow of solution (using a push-pull syringe) through a water-jacket heat exchanger.

The following extracellular solution (in mM) was used: $10 \mathrm{CaCl}_{2} ; 135$ tetraethylammonium-Cl (TEA-Cl); $10 \mathrm{~N}$-2-hydroxyethylpiperazine- $N^{\prime}$ 2-ethanesulfonic acid (HEPES), pH 7.4, adjusted with TEA-OH.

Intracellular (pipet) solution A was as follows (in $\mathrm{mM}$ ): $100 \mathrm{CsCl}, 1$ $\mathrm{Na}_{2} \mathrm{ATP}, 2.5 \mathrm{MgCl}_{2}, 0.3 \mathrm{Na}_{3} \mathrm{GTP}$ (Aldrich Chem. Co. Milwaukee, WI), 10 EGTA, $2.9 \mathrm{CaCl}_{2}(\mathrm{pCa}=7.0, \mathrm{pMg}=2.7), 40$ HFPES, $\mathrm{pH} 7.0$, adjusted with TEA-OH.

Intracellular solution $B$ was as follows: $100 \mathrm{CsCl}, 2 \mathrm{Na}_{2} \mathrm{ATP}$ (equine, Sigma), $5 \mathrm{MgCl}_{2}, 10$ ethyleneglycol-bis-( $\beta$-aminoethyl ether)-tetraacctic acid (EGTA), 40 HEPES, pH 7.0 adjusted with TEA-OH.

PMA and $4 \alpha$-phorbol (both from Sigma) were dissolved in dimethylsulfoxide as $2 \mathrm{~mm}$ stock solutions and stored at room temperature no more than 2 weeks. Experimental solutions were obtained by dilution from a $10 \mu \mathrm{M}$ stock (5\% DMSO, $95 \%$ water) prepared on the day of the experiment. 


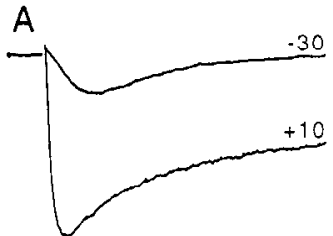

Figure 1. T current variation in 3 rat sensory neurons. Traces: Whole-cell currents evoked by steps from -70 to $-30 \mathrm{mV}$ ( $\mathrm{T}$ current) or $+10 \mathrm{mV}$ (sustained Ca currents). Vertical scale: 250 pA $(A), 1000 \mathrm{pA}(B), 1500 \mathrm{pA}(C)$. Graphs: peak current vs stimulus voltage. Cell capacitances: $31 \mathrm{pF}(A), 97 \mathrm{pF}$ $(B), 53 \mathrm{pF}(C)$. Temperature, $22^{\circ} \mathrm{C}$; intracellular solution $\mathrm{A}$.

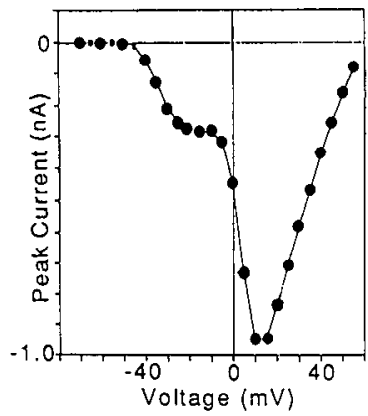

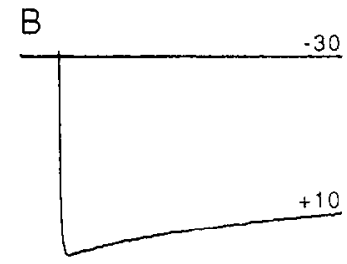
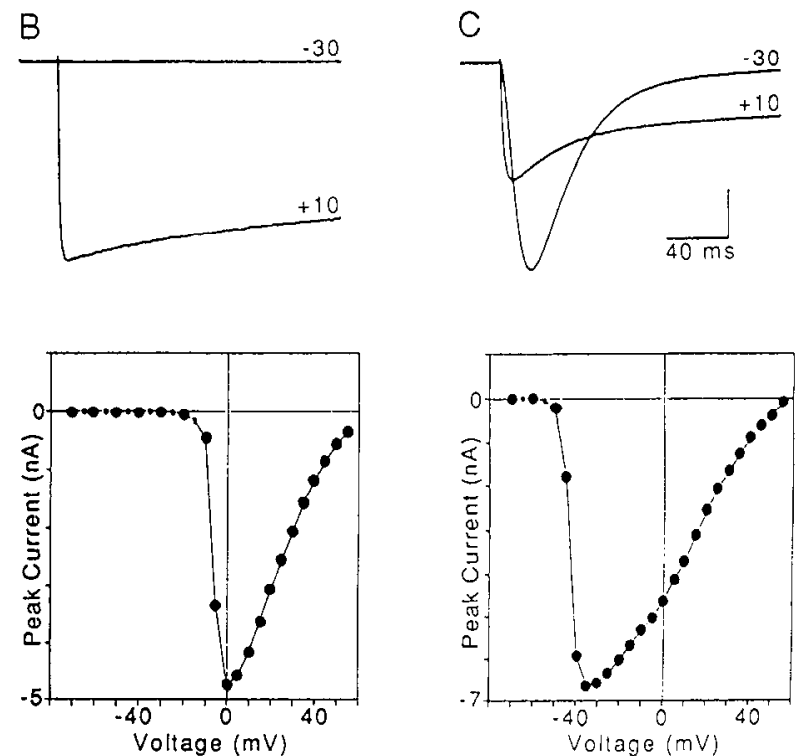

\section{Results}

\section{Heterogeneous expression of T-type Ca channels}

Figure 1 shows Ca currents recorded with the whole-cell patchclamp technique (Hamill et al., 1981) from 3 sensory neurons. The traces show currents evoked by steps to the indicated voltage from a holding voltage of $-70 \mathrm{mV}$; the graphs are plots of peak current against test voltage. Cell $\mathrm{A}$ has the classic signature of the T-type Ca channel: the step to $-30 \mathrm{mV}$ elicits a small, transient current, and there is a shoulder on the current-voltage curve at negative voltages. Steps to more positive voltages elicit a larger, more sustained current and result in a peak in the current-voltage curve at around $+10 \mathrm{mV}$. In contrast, cell $\mathrm{B}$ has no $\mathrm{T}$ current, whereas cell $\mathrm{C}$ has a $\mathrm{T}$ current, which is larger than the high-threshold current. The large $T$ current in Figure $1 C$ has a similar inactivation rate but reaches its peak slightly faster than the current in Figure $1 A$; the faster activation may be due to imperfect voltage control of neuronal processes.

The records of Figure 1 are representative of 3 kinds of responses. In a survey of 63 cells, $23 \%$ had no T current (like Fig. $1 B$ ) and $5 \%$ had very large $\mathrm{T}$ currents (like Fig. $1 C$ ). The remainder had the more classical response in which $\mathrm{T}$ current amplitude is a fraction (ranging from 5 to $75 \%$ ) of the peak highthreshold current. Scatter plots of $T$ current density against cell size showed no correlation. Though we lump these different responses into 3 categories, the "classical response" contains a wide range of $T$ channel amplitudes and may well have subsets within it.

There are 3 possible explanations of this variation in the level of T-type Ca current: (1) differences in hormonal modulation of $\mathrm{T}$ current in different cells; (2) variation in development in vivo or with time in tissue culture; and (3) different expression of $T$ channels on subsets of sensory neurons. We favor the final explanation. Neighboring cells in a culture dish routinely exhibit radically different levels of T-type current, so differences in hormonal modulation seem unlikely. We have found $T$ channel heterogeneity in adult sensory neurons, embryonic neurons and the newborns discussed here; thus, heterogeneity is not simply a manifestation of development. The differences exist among cells that are freshly dissociated, as well as those maintained in culture, so the observation is not an artifact of tissue culture.

Heterogeneous expression suggests that the $T$ channel might be a key determinant of different electrophysiological behavior of sensory neuron subpopulations. In particular, the giant $T$ current (like Fig. 1C) is similar in amplitude to $\mathrm{Na}$ currents seen in these neurons, indicating that the $T$ channel can have a controlling influence on the threshold and shape of the action potential in a subset of sensory cells (White et al., 1989).

\section{$T$ channels are inhibited by phorbol esters}

Figure 2 shows $\mathrm{T}$ currents, recorded at $32^{\circ} \mathrm{C}$, just before and within $100 \mathrm{sec}$ after application of the indicated phorbol esters. Phorbol 12-myristate 13-acetate (PMA), a phorbol ester which activates the calcium and phospholipid-dependent enzyme, protein kinase $\mathrm{C}$ (Nishizuka, 1986), diminishes the T current (Fig. $2 a, b) .4 \alpha$-Phorbol, an analog which does not affect the kinase (Nishizuka, 1986), has no effect on the T current (Fig. 2c). The average decrease in current with 10 nM PMA was $27 \%( \pm 6 \%$ $\mathrm{SD}, n=4)$. Elevated temperatures $\left(\geq 29^{\circ} \mathrm{C}\right)$ are required for inhibition by PMA; no effect was seen at room temperature, but inhibition could be induced by raising the temperature in the presence of PMA. The experimental conditions required for inhibition are reasonable for protein kinase $C$ effects: The temperatures are similar to those used for in vitro assays of protein kinase $C$ activity, $10 \mathrm{nM}$ is a submaximal PMA concentration for phosphorylation in vitro (Castagna et al., 1982), and the pipet solution provides a physiological intracellular $\mathrm{Ca}$ concentration $(0.1 \mu \mathrm{M})$. These results contrast with those from Aplysia bag cell neurons, in which acute effects of PMA were lost with internal perfusion (DeRiemer et al., 1985).

\section{The inhibition is selective}

Figure 3 compares the effects of PMA on T-type and highthreshold $\mathrm{Ca}$ currents. The insets of Figure 3, $a, b$, show $\mathrm{T}$ currents $a$ or high-threshold currents $b$ before and after application of PMA to 2 different cells. The graphs express peak current against the time of recording. Inhibition of $T$ channels occurs within $20 \mathrm{sec}$ of application of $10 \mathrm{nM}$ PMA, and there 
a.



b. 100nM PMA

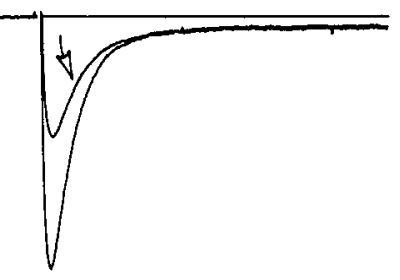

C. $100 \mathrm{nM} 4 \alpha-$ phorbol



Figure 2. Acute eflects of phorbol esters on $T$ current at elevated temperature. Recordings are just before and within $100 \mathrm{sec}$ after, application of the indicated phorbol ester. Holding potential: $-70 \mathrm{mV}$. Test potentials: $-30 \mathrm{mV}$ $(a, b)-20 \mathrm{mV}(c)$. Vertical scale: 400 pA (a), 1000 pA (b), 200 pA (c). Temperature, $32^{\circ} \mathrm{C}$; intracellular solution $\mathrm{A}$. is no indication of recovery in $3 \mathrm{~min}$ following washout, suggesting that dephosphorylation may be relatively slow. In contrast, 50 nM PMA has no effect on high-threshold current.

Figure $3 c$ shows results from a third cell from which currentvoltage curves were obtained before and after $5 \mathrm{~min}$ in $10 \mathrm{~nm}$ PMA. The traces show superimposed currents at the indicated test voltage in the absence and presence of PMA (traces at +40 $\mathrm{mV}$ exactly superimpose). The $\mathrm{T}$ currents at -40 and $-20 \mathrm{mV}$ show the inhibition typical of $10 \mathrm{nM}$ PMA, but there is no significant decrease in the high-threshold currents elicited at +20 and $+40 \mathrm{mV}$. In each of 4 experiments, we saw no inhibition of high-threshold Ca current by either 10 or 50 nM PMA.

\section{Selective inhibition in a population study}

Two concerns led us to verify the results of Figures 2 and 3 with an alternate method not involving recordings at elevated temperature. Cells tended to be unstable and short-lived at the elevated recording temperatures, limiting the number of successful experiments. Moreover, the instability led to selection of larger-amplitude $T$ currents since variation in holding current was less of a problem at the lower gain. Table 1 and Figure 4 describe data from a protocol in which cultures were preincubated at $37^{\circ} \mathrm{C}$, followed by recordings from many cells at room temperature. There was no evidence of damage to cells or selective cell death due to PMA incubations. Since all incubations were done at $37^{\circ} \mathrm{C}$, we did not show that this protocol was temperature-dependent, as was the acute application of phorbol ester in the previous section.
Table 1 compares the average Ca currents in cells incubated in $100 \mathrm{nM}$ PMA for 15-60 min with those in cells either untreated or incubated in the inactive phorbol ester, $4 \alpha$-phorbol. In all, 128 cells in paired sets from 7 rat preparations were studied. The data are presented for each rat preparation to show the variability of average currents. Despite this variability, incubation in PMA consistently increased the proportion of cells without detectable $\mathrm{T}$ current (41 vs $24 \%$, column 4 ) and decreased the average amplitude of $\mathrm{T}$ current among those cells in which it was measurable (column 5). The average high-threshold ("peak") current of PMA-treated cells was greater than control when all data were combined. This effect seemed to be due to one preparation (R32) which had an unusually large difference. Comparison of high-threshold current preparation by preparation shows that in 3 cases the average current was higher with PMA, in 2 cases it was lower, and in 2 it was within the standard error; this is different from the $\mathrm{T}$ current, which was diminished in each of the 7 preparations. The histogram of Figure 4 is a plot of the percentage of cells with the indicated $\mathrm{T}$ : peak current ratios (for each preparation except R32). $\chi^{2}$ analysis indicates with $>90 \%$ certainty that the increase in cells without T current is due to PMA. For cells which had T current, $P M A$ reduced the average $T$ : peak current ratio from $0.43( \pm 0.09$ SEM) to 0.11 ( \pm 0.02 SEM).

\section{Discussion}

The physiological effects of activation of protein kinase $\mathrm{C}$ vary greatly among different kinds of neurons (Kaczmarek, 1987).
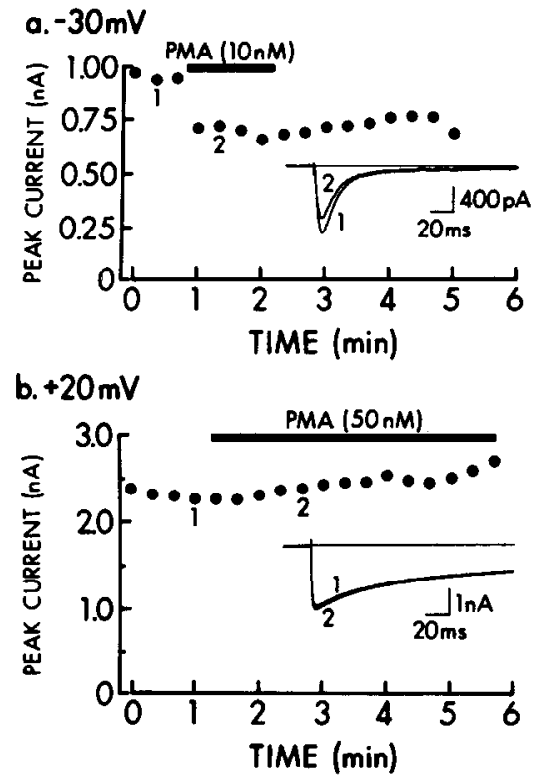

c. $10 \mathrm{nM}$ PMA
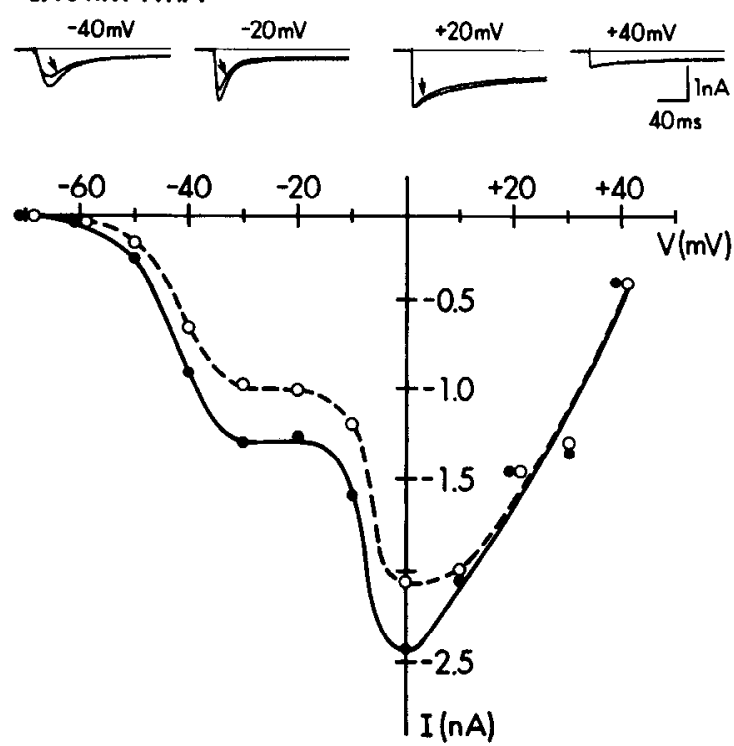

Figure 3. Selective inhibition of $\mathrm{T}$ current. $a$ and $b$, Peak T current ( $a$ ) or high-threshold current $(b)$ as a function of time during applications of $10 \mathrm{nм}(a)$ or $50 \mathrm{nM}(b)$ PMA to 2 different cells. Insets: Current records at the indicated times, before and after PMA application. Holding potentials: $-70 \mathrm{mV}$. Test potentials: $-30 \mathrm{mV}(a) ;+20 \mathrm{mV}(b)$. Temperatures: $33^{\circ} \mathrm{C}(a), 32^{\circ} \mathrm{C}(b) . c$, Peak current vs stimulus voltage before (solid symbols) and with (open symbols) 10 nM PMA. Traces: superimposed currents at the indicated test voltages before and with (arrows, except last traces which superimpose) $10 \mathrm{~nm}$ PMA. Temperature, $29^{\circ} \mathrm{C}$; intracellular solutions $\mathrm{A}$. 
DISTRIBUTION OF T : PEAK CURRENT AMPLITUDES

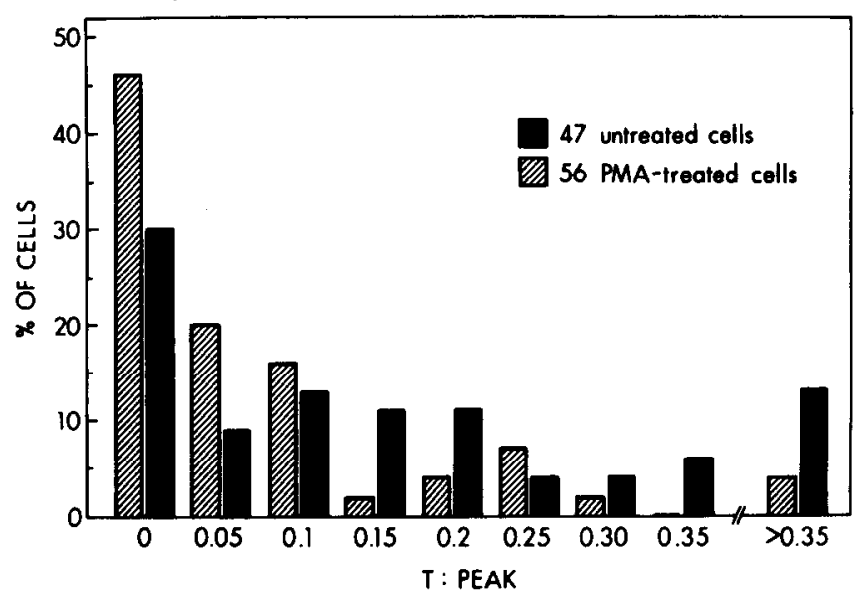

Figure 4. Histogram of the percentage of cells exhibiting the indicated ratio of peak $T$ current to peak total current. Pretreated cells (shaded bars) were incubated in culture medium containing $100 \mathrm{nM}$ PMA at $37^{\circ} \mathrm{C}$ for $15-60 \mathrm{~min}$. Control cells (solid bars) are from the 6 preparations which received no pretreatment. Recording temperature, $22^{\circ} \mathrm{C}$. Extracellular recording solution for pretreated cells also contained $100 \mathrm{~nm}$ PMA; intracellular solution $B$.

This is exemplified by the effects of protein kinase $\mathrm{C}$ on $\mathrm{Ca}$ channels: whereas $\mathrm{Ca}$ channel activity is enhanced in Aplysia bag cell neurons by unmasking an otherwise silent $\mathrm{Ca}$ channel (Strong et al., 1987), protein kinase C inhibits Ca channels in chick dorsal root ganglion neurons (Rane and Dunlap, 1986; Marchetti and Brown, 1988; Rane et al., 1989), snail neurons (Hammond et al., 1987), and secretory cell lines (Harris et al., 1986). Sensory neurons within the dorsal root ganglion are themselves a heterogeneous group of cells. They transduce and cncodc a variety of sensations and have been divided into subpopulations based on sensory receptor, conduction velocity, projection sites, peptide content, and surface antigens (Light and Perl, 1984; Dodd and Jessel, 1985). These subpopulations might be expected to display different physiological and pharmacological properties. The results of this paper suggest that protein kinase $\mathrm{C}$ selectively inhibits a type of voltage-dependent $\mathrm{Ca}$ channel that is absent on a subpopulation of rat dorsal root ganglion neurons and expressed at widely different degrees among others. Thus, activation of the kinase could diminish excitability of some sensory cells while leaving others unaffected, suggesting the potential for selective modulation of particular sensations.

Phorbol esters and diacylglycerol analogs have been shown to reduce Ca currents independently of protein kinase $\mathrm{C}$ activation (Hockberger et al., 1989). There are several differences between our results and the non-kinase effect. Both PMA and $4 \alpha$-phorbol caused the non-kinase inhibition, whereas $4 \alpha$-phorbol was ineffective in the present work. The non-kinase effect involved phorbol ester concentrations 1000 times greater than we have used, affected nonspecifically both T-type and highthreshold currents, did not require elevated temperature, and was rapidly reversible. In all these respects, our results differ from the non-kinase effect of phorbol esters. With regard to temperature sensitivity, our results are similar to the phorbol ester-induced potentiation of a cardiac K channel (Walsh and Kass, 1988).

These results in newborn rat sensory neurons differ from those in chick embryonic neurons. Phorbol esters and diacylglycerol analogs inhibit both high-threshold and T-type Ca currents in chick sensory neurons (Rane and Dunlap, 1986; Marchetti and Brown, 1988; Rane et al., 1989), rather than the specific $T$ channel effect we report in rat. The results on chick neurons certainly are not due to the non-kinase effect of Hockberger et al. (1989): a phorbol ester which does not affect protein kinase $C$ was used as a control (Rane and Dunlap, 1986) and inhibitors of protein kinase C block the effect (Rane et al., 1989). Are the differences in the chick and rat results due to species or exper-

Table 1. Comparison of Ca currents in cells preincubated in PMA (100 nM for 15-60 min) to either untreated cells or cells incubated in $4 \alpha-$ phorbol

\begin{tabular}{|c|c|c|c|c|c|c|}
\hline Prep. & Incubation & Cells & $\begin{array}{l}\text { Cells } \\
\text { w/o T }\end{array}$ & $\begin{array}{l}\text { Averge } \mathrm{T} \\
(\mathrm{pA})\end{array}$ & $\begin{array}{l}\text { Average peak } \\
(\mathrm{pA})\end{array}$ & $\begin{array}{l}\text { Average } \\
\text { T:Peak }\end{array}$ \\
\hline \multirow[t]{2}{*}{ R08 } & PMA & 4 & 3 & -23 & $-1510 \pm 218$ & 0.020 \\
\hline & None & 2 & 0 & $-257 \pm 165$ & $-1950 \pm 115$ & $0.198 \pm 0.148$ \\
\hline \multirow[t]{2}{*}{$\mathrm{R} 14$} & PMA & 2 & 1 & -114 & $-880 \pm 114$ & 0.149 \\
\hline & None & 5 & 0 & $-114 \pm 27$ & $-983 \pm 177$ & $0.132 \pm 0.04$ \\
\hline \multirow[t]{2}{*}{$\mathrm{R} 17$} & PMA & 14 & 8 & $-72 \pm 10$ & $-1860 \pm 297$ & $0.053 \pm 0.007$ \\
\hline & None & 10 & 3 & $-130 \pm 40$ & $-1060 \pm 201$ & $0.153 \pm 0.031$ \\
\hline \multirow[t]{2}{*}{$\mathrm{R} 18$} & PMA & 10 & 7 & $-55 \pm 16$ & $-1470 \pm 288$ & $0.054 \pm 0.016$ \\
\hline & None & 10 & 5 & $-173 \pm 33$ & $-1030 \pm 144$ & $0.233 \pm 0.085$ \\
\hline \multirow[t]{2}{*}{$\mathrm{R} 20$} & PMA & 18 & 4 & $-100 \pm 18$ & $-1290 \pm 21$ & $0.155 \pm 0.45$ \\
\hline & None & 7 & 2 & $-457 \pm 314$ & $-1510 \pm 490$ & $0.329 \pm 0.155$ \\
\hline \multirow[t]{2}{*}{$\mathrm{R} 21$} & PMA & 8 & 3 & $-112 \pm 15$ & $-1420 \pm 404$ & $0.173 \pm 0.042$ \\
\hline & None & 13 & 4 & $-341 \pm 164$ & $-731 \pm 122$ & $0.607 \pm 0.282$ \\
\hline \multirow[t]{2}{*}{ R32 } & PMA & 10 & 1 & $-98 \pm 32$ & $-2364 \pm 431$ & $0.058 \pm 0.020$ \\
\hline & $4 \alpha$-phorbol & 15 & 1 & $-881 \pm 297$ & $-1248 \pm 213$ & $0.695 \pm 0.203$ \\
\hline \multirow[t]{2}{*}{ All cells } & PMA & 66 & 27 & $-92 \pm 10$ & $-1619 \pm 135$ & $0.108 \pm 0.02$ \\
\hline & Control & 62 & 15 & $-437 \pm 107$ & $-1106 \pm 93$ & $0.429 \pm 0.09$ \\
\hline
\end{tabular}

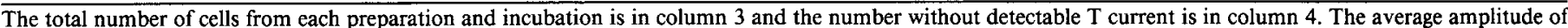

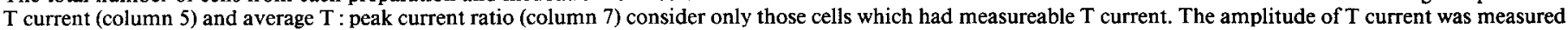
with pulses to $-30 \mathrm{mV}$; peak current was measured with pulses to $+10 \mathrm{mV}$. SEM is used throughout. 
imental differences? The results on chick neurons were obtained at room temperature and involved higher phorbol ester concentrations than were used in our studies. In contrast, we see no effect of PMA on any rat $\mathrm{Ca}$ current at room temperature, even with $100 \mathrm{~nm}$ PMA. Nonspecific effects of phorbol esters at elevated temperature and higher PMA concentrations were difficult to rule out since these conditions generally killed our cells within tens of seconds during recordings. However, cells tolerated incubation in $100 \mathrm{~nm}$ PMA if they were not being patch-clamped, allowing preincubation experiments at this higher concentration. Since preincubation with high concentrations and acute application of low concentrations of PMA both cause selective loss of $T$ current, we are convinced of a real difference in the specificity of phorbol ester effects between rat and chick sensory neurons.

Selective effects on $\mathrm{T}$ channels have been reported in 3 other cases, but the biochemical mechanisms are not known: (1) transformation of fibroblasts with several unrelated oncogenes leads to a loss of $\mathrm{T}$ channel activity without effect on $\mathrm{L}$ channels (Chen et al., 1988); (2) T current increases upon binding of monoclonal antibodies to the Thy- 1 receptor on mouse sensory neurons (Saleh et al., 1988); (3) low concentrations of glutamate selectively inhibit $\mathrm{T}$ current in rat sensory neurons (Lovinger and Weight, 1988). All these may be candidates for involvement of protein kinase C.

\section{References}

Armstrong, C. M., and D. R. Matteson (1985) Two distinct populations of calcium channels in a clonal line of pituitary cells. Science 227: 65-67.

Bean, B. P. (1989) Classes of calcium channels in vertebrate cells. Annu. Rev. Physiol. 51: 367-385.

Bossu, J. L., and A. Feltz (1986) Inactivation of the low-threshold transient calcium current in rat sensory neurones: Evidence for a dual process. J. Physiol. (Lond.) 376: 341-357.

Bossu, J. L., A. Feltz, and J. M. Thomann (1985) Depolarization elicits two distinct calcium currents in vertebrate sensory neurons. Pfluegers Arch. 403: 360-368.

Carbone, E., and H. D. Lux (1984) A low voltage-activated, fully inactivating $\mathrm{Ca}$ channel in vertebrate sensory neurones. Nature 310 : $501-503$.

Carbone, E., and H. D. Lux (1987) Kinetics and selectivity of a lowvoltage-activated calcium current in chick and rat sensory neurones. J. Physiol. (Lond.) 386: 547-570.

Castagna, M., Y. Takai, K. Kaibuchi, K. Sano, U. Kikkawa, and Y. Nishizuka (1982) Direct activation of calcium-activated, phospholipid-dependent protein kinase by tumor-promoting phorbol esters. J. Biol. Chem. 257: 7847-7851.

Chen, C., M. J. Corbley, T. M. Roberts, and P. Hess (1988) Voltagesensitive calcium channels in normal and transformed $3 \mathrm{~T} 3$ fibroblasts. Science 239: 1024-1026.

DeRiemer, S. A., J. A. Strong, K. A. Albert, P. Greengard, and L. K. Kaczmarek (1985) Enhancement of calcium current in Aplysia neurones by phorbol ester and protein kinase C. Nature 313: 313-316.

Dodd, J., and T. M. Jessell (1985) Lactoseries carbohydrates specify subsets of dorsal root ganglion neurons projecting to the superficial dorsal horn of rat spinal cord. J. Neurosci. 512: 3278-3294.

Fedulova, S. A., P. G. Kostyuk, and N. S. Vesclovsky (1985) Two types of calcium channels in the somatic membrane of new-born rat dorsal root ganglion neurones. J. Physiol. (Lond.) 359: 431-446.

Fox, A. P., M. C. Nowycky, and R. W. Tsien (1987a) Kinetic and pharmacological properties distinguishing three types of calcium currents in chick sensory neurones. J. Physiol. (Lond.) 394: 149-172.

Fox, A. P., M. C. Nowycky, and R. W. Tsien (1987b) Single-channel recordings of three types of calcium channels in chick sensory neurones. J. Physiol. (Lond.) 394: 173-200.
Hagiwara, N., H. Irisawa, and M. Kameyama (1988) Contribution of two types of calcium currents to the pacemaker potentials of rabbit sino-atrial node cells. J. Physiol. (Lond.) 395: 233-253.

Hamill, O. P., A. Marty, E. Neher, B. Sakmann, and F. J. Sigworth (1981) Improved patch-clamp tcchniques for high-resolution current recording from cells and cell-free membrane patches. Pfluegers Arch. 391: 85-100.

Hammond, C., D. Paupardin-Tritsch, A. C. Nairn, P. Greengard, and H. M. Gerschenfeld (1987) Cholecystokinin induces a decrease in $\mathrm{Ca}^{2+}$ current in snail neurones that appears to be mediated by protein kinase C. Nature 325: 809-811.

Harris, K. M., S. Kongsamut, and R. J. Miller (1986) Protein kinase $\mathrm{C}$ mediated regulation of calcium channels in PC-12 pheochromocytoma cells. Biochem. Biophys. Res. Commun. 134: 1298-1305.

Hockberger, P., M. Toselli, D. Swandulla, and H. D. Lux (1989) A diacylglycerol analogue reduces neuronal calcium currents independently of protein kinase $C$ activation. Nature 338: 340-342.

Jahnsen, H., and R. Llinás (1984) Ionic basis for the electroresponsiveness and oscillatory properties of guinea-pig thalamic ncuroncs in vitro. J. Physiol. (Lond.) 349: 227-247.

Kaczmarek, L. K. (1987) The role of protein kinase $C$ in the regulation of ion channels and neurotransmitter release. Trends Neurosci. 10: 30-34.

Kostyuk, P. G., and R. E. Shirokov (1989) Deactivation kinetics of different components of calcium inward current in the membrane of mice sensory neurones. J. Physiol. (Lond.) 409: 343-355.

Light, A. R., and E. R. Perl (1984) Peripheral sensory systems. In Peripheral Neuropathy, P. J. Dyck, P. K. Thomas, E. H. Lambert, and R. Bunge, eds., Saunders, Philadelphia.

I ovinger, D. M., and F. F. Weight (1988) Glutamate inhibits the lowthreshold, transient calcium current in dorsal root ganglion neurons acutely isolated from adult rat. Soc. Neurosci. Abstr. 14: 792.

Marchetti, C., and A. M. Brown (1988) Protein kinase activator l-olcoyl-2-acetyl-sn-glycerol inhibits two types of calcium currents in $\mathrm{GH}_{3}$ cells. Am. J. Physiol. 254: C206-C210.

Matteson, D. R., and C. M. Armstrong (1986) Properties of two types of calcium channels in clonal rat pituitary cells. J. Gen. Physiol. 87: 161-182.

McCormick, D. A., and D. A. Prince (1988) Noradrenergic modulation of firing pattern in guinea pig and cat thalamic neurons. J. Neurophysiol. 593: 978-995.

Nishizuka, Y. (1986) Studies and perspectives of protein kinase C. Science 233: 305-312.

Nowycky, M. C., A. P. Fox, and R. W. Tsien (1985) Three types of neuronal calcium channel with different calcium agonist sensitivity. Nature 316: 440-443.

Rane, S. G., and K. Dunlap (1986) Kinase Cactivator 1,2-oleoylacetylglycerol attenuates voltage-dependent calcium current in sensory neurons. Proc. Natl. Acad. Sci. USA 83: 184--188.

Rane, S. G., M. P. Walsh, J. R. McDonald, and K. Dunlap (1989) Specific inhibitors of protein kinase $C$ block transmitter-induced modulation of sensory neuron calcium current. Neuron 3: 239-245.

Saleh, M., R. J. Lang, and P. F. Bartlett (1988) Thy-1-mediated regulation of a low-threshold transient calcium current in cultured sensory neurons. Proc. Natl. Acad. Sci. USA 85: 4543-4547.

Strong, J. A., A. P. Fox, R. W. Tsien, and L. K. Kaczmarek (1987) Stimulation of protein kinase $C$ recruits covert calcium channels in Aplysia bag cell neurons. Nature 325: 714-717.

Tsien, R. W., D. Lipscombe, D. V. Madison, K. R. Bley, and A. P. Fox (1988) Multiple types of neuronal calcium channels and their selective modulation. Trends Neurosci. 11: 431-437.

Walsh, K. B., and R. S. Kass (1988) Regulation of a heart potassium channel by protein kinase A and C. Science 242: 67-69.

White, G., D. M. Lovinger, and F. F. Weight (1989) Transient lowthreshold $\mathrm{Ca}^{2+}$ current triggers burst firing through an afterdepolarizing potential in an adult mammalian neuron. Proc. Natl. Acad. Sci. USA 86: 6802-6806.

Yamamoto, M., H. W. M. Steinbusch, and T. M. Jessel (1981) Differentiated properties of identified serotonin neurons in dissociated cultures of embryonic rat brain stem. J. Cell Biol. 91: 142-152. 